\title{
Fiscal Decentralization in China and India: Competitive, Cooperative or Market Preserving Federalism?
}

\author{
January 2007 \\ Nirvikar Singh* \\ Department of Economics \\ and \\ Santa Cruz Center for International Economics \\ University of California, Santa Cruz
}

\begin{abstract}
This paper provides a comparative assessment of fiscal decentralization in China and India, including the standard components of expenditure and revenue assignments and institutions for intergovernmental transfers, as well as the nature of subnational authorities over general economic activity. In particular, the case of China, where town and village enterprises have been very active, is contrasted with that of India, where local governments remain circumscribed in their authority, despite decentralizing reforms. The implications of differences in decentralization for fiscal outcomes and economic growth are discussed. The characterization of each country in terms of concepts of federalism, i.e., competitive, cooperative and market preserving federalism, is discussed, in attempting to abstract from the two cases to more general lessons for fiscal decentralization.
\end{abstract}

Keywords: cooperative federalism, competitive federalism, market-preserving federalism, decentralization, economic development.

JEL codes: P26, P35, H1, H7

\footnotetext{
* Dept. of Economics, E2 Building, University of California, Santa Cruz, CA 95064, boxjenk@ucsc.edu, 831-459-4093.
} 


\section{Introduction}

China and India are the major global growth stories of the past decade. Their size and their high growth rates imply that, if they continue on their current trajectories, there will be a significant shift in the world's economic landscape. In each country, despite differences in historical circumstances and policies, growth has been accompanied by, and almost certainly driven by, a shift toward greater market orientation in economic policies. International trade, investment, technology adoption and private enterprise are all components of the two countries' recent economic success.

While redrawing the boundaries between state and market has been a wellrecognized factor in China and India's growth accelerations, a subtler aspect of governance involves the decentralization of government decision-making. This kind of decentralization can have two potential positive effects on economic activity and growth. First, it can improve the efficiency of delivery of public goods, which may be complementary to private goods in supporting economic activity (e.g. infrastructure). Second, it can be a facilitating channel for implementing changes in the boundary between public and private economic activity, by restraining the power of government decision makers. In each case, the potential driving force, as usually theorized, is greater accountability through greater competition among government decision-makers for approval of constituents. In the Chinese case, however, the personal gain of local government decision-makers may also have been a motivating factor. Thus, the benefits of decentralization, and the channels through which it works, are not necessarily straightforward. In addition, competition and local government capture of economic rents may have negative impacts, including underprovision of public goods and rent-seeking burdens on private enterprise.

Therefore, this paper examines the relative nature and impacts of fiscal decentralization in China and India, with the goal of understanding the role of decentralization in the two countries' economic growth. We include a summary of the standard components of expenditure and revenue assignments and institutions for intergovernmental transfers, as well as the nature of subnational authorities over general economic activity. In particular, the case of China, where town and village enterprises have been very active, is contrasted with that of India, where local governments remain circumscribed in their authority, despite decentralizing reforms. The implications of differences in decentralization for fiscal outcomes and economic growth are discussed. The characterization of each country in terms of concepts of federalism, i.e., competitive, cooperative and market preserving federalism, is discussed, in attempting to abstract from the two cases to more general lessons for fiscal decentralization.

The remainder of the paper is structured as follows. Section 2 provides an overview of federal institutions in the two countries, including assignments of authority. Section 3 explores a theoretical framework for comparing the two countries' experience, using the ideas of market preserving, competitive and cooperative federalism. The key focus is on the impact of subnational government spending on private sector productivity, and how subnational spending is affected by different institutional assignments of tax authority and rules for tax sharing. Section 4 examines the decentralization experience of India and 
China, relating it to the conceptual models introduced in the previous section. A summary conclusion is provided in section 5.

\section{Federal Systems in China and India ${ }^{1}$}

China has a unitary system of government, albeit with several tiers, including provinces and local governments. The latter category includes, in descending order of size, prefectures, counties and townships (Table 1). A constant feature of China, in contrast to India, has been a strong, centralized, one-party system. This institutional arrangement has dominated politics, but allowed considerable experimentation and variation in terms of economic authority at different levels of government. Before the 1980s Chinese reforms, which began the country's sustained growth spurt, taxes and nontax revenues (i.e., profits from state enterprises) were collected by provincial governments acting as agents of the center. Expenditure planning was a centralized topdown process, as was the determination of revenue sharing. With reform, there was an attempt to create a fiscal contracting system to govern explicit sharing of revenues by the provinces with the center. However, the increased economic resources of several provinces gave them incentives to manipulate the system to shelter revenues from sharing with the center, resulting in fiscal stress at the center. ${ }^{2}$ In addition to the contracted transfers, there was also discretionary borrowing by the center from provinces, and transfer payments by the center to other provinces.

At this stage, centralization of political power asserted itself, and in 1994, the institutional arrangements finally moved toward a more traditional tax system, with a separate national tax collection bureau, and taxes that are shared (including a central VAT), as well as others that are assigned to one level of government or another. ${ }^{3}$ China was ahead of India with respect to the introduction of a VAT. However, "extrabudgetary” revenues, which include tax surcharges, user fees and some state enterprise profits, are quite significant, and even institutionalized. Given these features, and the somewhat opaque nature of Chinese government budgeting and national income accounting, it has been more difficult to conduct an analysis of the Chinese tax system than has been the case for India. However, a recent comprehensive study (Asian Development Bank, 2005) documents the size and nature of tax revenues as well as extrabudgetary revenues. ${ }^{4}$ The former include the VAT (36 percent of budgetary revenues, and business and company income taxes (14 percent each). The latter constitute about 4 percent of GDP, almost all being at the subnational level.

\footnotetext{
${ }^{1}$ This section draws on my previous work on these countries, including joint work with M. Govinda Rao and T. N. Srinivasan.

${ }^{2}$ Many references have detailed accounts of this process, e.g., Montinola, Qian and Weingast (1995). The central government's share of total revenue declined from about 40 percent in 1985 to less than 25 percent in 1993. At the same time, total government revenue also declined as a fraction of GDP, from 29 percent in 1980 to less than 12 percent of GDP in 1994 (Fedelino and Ter-Minassian, 2006).

${ }^{3}$ Currently, government revenue is about 17 percent of GDP, and the central government has a share of about 55 percent (Fedelino and Ter-Minassian, 2006).

${ }^{4}$ Also, see Rao (2003), Bahl and Martinez-Vazquez (2005) and Fedelino and Ter-Minassian (2006) for some observations on the Chinese tax system.
} 
Intergovernmental transfers in China have been subject to various regimes, as noted, with different formulas and principles used for revenue sharing. Understanding the growth impacts of intergovernmental transfers requires some modeling of how subnational governments can affect their tax bases. From this perspective, the marginal subnational retention rate of all taxes levied on the subnational tax base comes into play. Jin, Qian and Weingast (2005) calculated the marginal retention rate for China during the high growth phase of reform, 1981-92, and estimated the average marginal retention rate for a province at 89 percent, with 68 percent of the provinces having marginal retention rates of 100 percent. Subsequently, however, the reliance of subnational government on transfers increased, due to the centralization of taxes in 1994. Currently, transfers account for about 45 percent of subnational revenues (Asian Development Bank, 2005, Table 15). However, Jin, Qian and Weingast (2005) argue that the effective marginal retention rates in the new (post-1994) system are similar to those in the early reform period. ${ }^{5}$

To sum up, in China, strong local and provincial fiscal autonomy can be seen as establishing a de facto federal structure, even in the absence of legally-based political and bureaucratic institutions of federalism. In this view, subnational fiscal autonomy on the revenue side works in both directions, up and down, so that, in this respect, it is supportive of hard budget constraints. ${ }^{6}$ At the same time, this arrangement may be less amenable to managing regional inequalities, which may be emerging as a serious problem in the case of China, threatening to get beyond the central government's ability to manage them (Fedelino and Ter-Minassian, 2006). Furthermore, as we discuss in section 4, there may be emerging fiscal problems at the local, as opposed to provincial, level of China's subnational governments.

India, in contrast to China, is a constitutional democracy, with explicitly federal features, albeit biased toward central control. There are directly elected parliamentarystyle governments at the national and state level, as well as relatively new directly elected government bodies at various local levels (separated into urban governments of various sizes and three tiers of rural government - district, block and village group; see Table 1). Overlapping political authorities at the central and state levels were dealt with through intra-party bargaining in the 1950s and early 1960s, in an era of effective single-party rule. More recently, the rise of regional parties in states and their presence in national coalitions has led to more explicit bargaining.

India's constitution spells out in some detail the assignment of taxation powers and expenditure responsibilities among states, and mandates the appointment of a Finance Commission every five years to make recommendations on tax sharing between center and states, and among the states. In 1993, constitutional amendments mandated state finance commissions to oversee state-local transfers. In 1950, an extra-constitutional body, the Planning Commission, was established, and it makes grants to states in support of their five-year plans (which the Commission formally approves). Also, central

\footnotetext{
${ }^{5}$ Shah and Shen (2006) provide a recent analysis and suggestions for reform of the Chinese intergovernmental transfer system.

${ }^{6}$ See, in particular, Montinola, Qian and Weingast (1995), Cao, Qian and Weingast (1999) and Jin, Qian and Weingast (2005).
} 
ministries make their own grants in support of centrally sponsored schemes to be implemented by the states. Various formulas are used in determining transfers, but considerable discretion remains at the margin, and there are issues of coordinating transfers recommended by the Finance Commission and the Planning Commission. The Finance Commission's goals include equity, efficiency, predictability and stability. Its transfers are meant to correct both vertical (between center and states) and horizontal (among the states) imbalances. The vertical imbalance reflects in large part the constitutional provisions relating to taxes and expenditure responsibilities. Horizontal imbalances depend not only on differential capacities, needs and costs, but also on the efficiency with which capacities are used to deliver services at the least possible cost.

In 2004-2005, the states on average raised about 39 percent of combined government revenues, but incurred about 66 percent of expenditures. ${ }^{7}$ Transfers from the center, including tax-sharing, grants and loans made up most of the difference, with the states also borrowing moderately from other sources. Focusing on current expenditure only, states financed about 58 percent of that total from their own sources of revenue in 2004-05, up from 52 percent in 2002-2003, but considerably lower than the ratio that had prevailed in the early days of the federation. In terms of total expenditure (including capital spending), the states covered only about 42 percent by their own revenue receipts in that year. There has always been considerable variation across the states in their transfer dependence, and the ranking is not completely determined by per capita income. For the three years 2000-2003, of the 16 larger states, the ratio of own revenue to revenue expenditure ranged from 78 percent to 25 percent (Finance Commission, 2004, Annexure 7.10).

While India never took measures such as collectivization, the central and state governments followed a philosophy similar to that of China in producing goods and services for which more cost-effective alternatives in the private sector have always existed or have come into existence in recent decades. Public enterprises in India, as in the Chinese case, have significant impacts on the revenues, expenditure and borrowing of governments at all levels. Indeed, the use of such enterprises for borrowing under state guarantees has created contingent liabilities for the states, besides being a non-transparent device to raise resources outside the formal budget. In India, contingent liabilities from guarantees in support of loss-making public enterprises constitute about 12 percent of GDP. This is in addition to the existing debt of these enterprises, which is about 10 percent of GDP.

\section{Theoretical Perspectives}

Conceptual or theoretical discussions of federalism encompass a wide variety of perspectives, including law, politics and economics. Here we are focused on implications of federal structures for economic development. Thus, we abstract from details of legal and political institutions in sketching a theoretical framework that allows comparing the

\footnotetext{
${ }^{7}$ These figures are constructed from various tables in Reserve Bank of India (2006). Both proportions do vary somewhat from year to year, and have been subject to political cycles. The estimated figures for 200506, calculated from the same source, were 38 percent of revenue and 60 percent of expenditure.
} 
Chinese and Indian cases. At the same time, it is useful to consider overall conceptions of federalism that have been postulated by scholars outside economics. In particular, cooperative, competitive and market-preserving federalism seem to be the most relevant descriptors of federalism. Of these, the idea of cooperative federalism has the longest history, but is the fuzziest. Various cases of practical cooperation in federations have been described, but they often involve noncooperative bargaining or central monitoring and control, rather than cooperation in the form of binding agreements. Competitive federalism is associated especially with the writings of Albert Breton $(1987,1996)$, and applies the insights of market competition to the government arena. Market-preserving federalism (MPF) is a term explicitly coined by Barry Weingast (1993), and has the most explicit structure associated with it.

Specifically, MPF is defined by five conditions: (1) a hierarchy of governments with delineated authorities (the basis of federalism); (2) primary authority over local economies for subnational governments; (3) a common national market enforced by the national government; (4) hard subnational government budget constraints; and (5) institutionalized allocation of political authority. MPF is of particular interest in comparing India and China because it has been used as a benchmark concept for both countries. While there has been a debate about where India's federal system fits the MPF system (Parikh and Weingast, 1997; Rodden and Rose-Ackerman, 1997), China has been characterized as firmly within the MPF locus, with appropriately decentralized political and economic decision-making, and only a common national market somewhat lacking (Montinola, Qian and Weingast, 1995).

We provide some minimal theoretical structure needed to elucidate the relevance of various features of federalism to promoting economic development. While there is already a large literature, with many different assumptions possible, our formulation is designed to make some specific points with respect to the interaction of subnational government decisions, private economic activity, and overall welfare. Consider, therefore, an economy with $\mathrm{N}$ subnational jurisdictions, indexed by $\mathrm{n}=1, \ldots \mathrm{N}$. It is convenient to assume homogeneity within jurisdictions, so that each can be characterized by a representative consumer. It is also convenient to assume that the jurisdictions are of equal size, normalized to 1 .

The utility of a representative citizen of jurisdiction $\mathrm{n}$ is given by

where $g_{n}$ is the amount of the subnational public good in that jurisdiction, $g_{-n}$ is the vector of public goods in all other jurisdictions, $\mathrm{G}$ is the amount of the national public good, $\theta$ is a preference parameter, and $x_{n}$ is the consumption of the private good. The function $\mathrm{U}($.) is assumed to be strictly concave. We are also assuming, for simplicity, that the private good enters utility in a linearly separable manner. The presence of the vector $\mathbf{g}_{\text {-n }}$ allows for public good spillovers across jurisdictions, in addition to the implicit spillover effects of the national public good.

There is an endowment of an input used to produce the private good, and this endowment level is $\mathrm{m}_{\mathrm{n}}$. The production function for the private good is given by 


$$
y_{n}=f\left(m_{n}, g_{n}\right) .
$$

Hence we assume that the productivity of the private sector depends on the supply of subnational public goods - we also assume for simplicity that the national public good has no such effect. ${ }^{8}$

The public goods are financed by proportional national and subnational taxes at respective rates $\mathrm{T}$ (uniform across jurisdictions) and $\mathrm{t}_{\mathrm{n}}$ on the private good, and public goods are produced using these tax proceeds, with constant unit costs, so

$$
\begin{aligned}
& c_{n} g_{n}=t_{n} y_{n}, \text { and } \\
& c G=T \Sigma y_{n} .
\end{aligned}
$$

Finally, consumption of the private good is determined by after-tax output,

$$
x_{n}=\left(1-t_{n}-T\right) y_{n} \text {. }
$$

If we substitute (5) in (1), we get the following form for the utility function,

$$
U\left(g_{n}, g_{-n}, G, \theta\right)+\left(1-t_{n}-T\right) y_{n} .
$$

Furthermore, we may substitute (2) through (4) into (6), yielding an expression for the utility function as follows:

$$
\mathrm{U}\left(\mathrm{g}_{\mathrm{n}}, \mathbf{g}_{-\mathrm{n}}, \mathrm{G}, \theta\right)+\mathrm{f}\left(\mathrm{m}_{\mathrm{n}}, \mathrm{g}_{\mathrm{n}}\right)-\mathrm{c}_{\mathrm{n}} \mathrm{g}_{\mathrm{n}}-\mathrm{cGf}\left(\mathrm{m}_{\mathrm{n}}, \mathrm{g}_{\mathrm{n}}\right) / \Sigma \mathrm{f}\left(\mathrm{m}_{\mathrm{i}}, \mathrm{g}_{\mathrm{i}}\right) \text {. }
$$

This expression includes only the levels of the public goods, having incorporated the costs and trade-offs of producing the private good and funding the production of the public goods.

The constituents of jurisdiction $n$ will determine the most preferred choice of the subnational and national public goods by maximizing (7) with respect to $\mathrm{g}_{\mathrm{n}}$ and $\mathrm{G}$. Given $\mathrm{G}$ and the vector $\mathbf{g}$, the tax rates and levels of private consumption would be determined by (2) through (5). Note that there are several interdependencies among the jurisdictions. Even if there are no direct spillovers in the utility function, we can see that the preferred level of $g_{n}$ will depend on $\mathbf{g}_{-n}$ through the last term in (7), which reflects the funding of the national public good. This interdependence arises because of the effects of the subnational public good on local productivity in producing the private good. Furthermore, the preferred level of $g_{n}$ will depend on $G$, the level of the national public good, through direct interactions, as well as through the last term in (7) - in this case, the level of $\mathrm{G}$ matters irrespective of any dependence of local private sector productivity on the level of public goods, simply because of the financing effect.

Since, by assumption, constituents in each subnational jurisdiction have homogeneous preferences, there is unanimity within each such jurisdiction with respect

\footnotetext{
${ }^{8}$ This idea is central to the argument in Careaga and Weingast (2001), and captures a key underlying idea of MPF, namely that subnational government decisions subject to some kind of discipline - competitive or electoral - promote economic development. In Qian and Roland (1998), subnational governments can invest in infrastructure, which has the productivity effect posited here. They also have a separate subnational public good, which allows for an additional tradeoff to those considered in this paper, where $\mathrm{g}_{\mathrm{n}}$ essentially serves both roles combined. Heady (1998) models a similar tradeoff to Qian and Roland, and uses it to interpret data for four Chinese cities.
} 
to the level of the subnational public good. However, each jurisdiction will have a different most-preferred level of the national public good. A standard majority rule argument will imply that the preferences of the median jurisdiction, when ordered by the most-preferred level of $G$, will prevail, provided that preferences are single-peaked. We assume that this is the case. In brief, then, there will be $n+1$ first order conditions ${ }^{9}$ that determine the $n+1$ public good levels, $G$ and the vector $\mathbf{g}$.

The presence of interaction effects implies that there is no presumption of optimality from decentralized decision-making in this setup. Pareto optimality implies maximizing a weighted sum of utilities. Since utilities are linear in the private good, an interior allocation will require the weights to be equal. In that case, the social welfare function is

$$
\Sigma \mathrm{U}\left(\mathrm{g}_{\mathrm{n}}, \mathbf{g}_{-\mathrm{n}}, \mathrm{G}, \theta\right)+\Sigma \mathrm{f}\left(\mathrm{m}_{\mathrm{n}}, \mathrm{g}_{\mathrm{n}}\right)-\Sigma \mathrm{c}_{\mathrm{n}} \mathrm{g}_{\mathrm{n}}-\mathrm{cG} \text {. }
$$

Here, the optimal level of the national public good satisfies the standard Samuelson condition that the sum of marginal utilities with respect to $G$ equals the marginal cost, in this case c.

It is useful to compare this with the outcome of decentralized expression of preferences by individual jurisdictions. Each jurisdiction considers only its own marginal benefit from the national public good, neglecting the benefits to other jurisdictions. However, it also does not weigh the full cost, but only its share, $f\left(m_{n}, g_{n}\right) / \Sigma f\left(m_{k}, g_{k}\right)$. If all jurisdictions are identical in all ways, the two mechanisms yield the same result, but in general distributional factors will come into play, when there are subnational heterogeneities. There is no general result, however, with respect to under or over provision of the national public good.

One can also compare the decentralized and Pareto optimal choices of $\mathrm{g}_{\mathrm{n}}$. The effects of direct spillovers are obvious, in driving a wedge between the two cases, so let us assume for the moment that they are absent. In that case, $\mathrm{g}_{\mathrm{n}}$ enters the first three terms of (7) and (8) in an identical manner, and the only difference comes about from the last term of (7). Essentially, increasing $g_{n}$ increases the jurisdiction's share of the aggregate tax base, and therefore its contribution to the national public good. In decentralized decision-making, this is treated as an extra cost, one that is not in the social welfare maximizing calculus. This effect is also not considered in models that examine only subnational decisions, or that do not consider the impact of subnational public goods on the local tax base. The result here is that decentralized preferences will tend to underprovide the subnational public good, because of the indirect externality operating through the payment sharing for the national public good. ${ }^{10}$

\footnotetext{
${ }^{9}$ We assume throughout that all objective functions have the required curvature so that first-order conditions are sufficient to characterize all maxima.

${ }^{10}$ This is similar to the issue raised in Careaga and Weingast (2001). In that formulation, the national public good is financed by sharing upwards of local tax revenues. Hence, if there is a uniform fraction, say, $\beta$, that is claimed by the national government, the government budget constraints become $c_{n} g_{n}=(1-\beta) t_{n} y_{n}$ and cG $=\beta \Sigma \mathrm{t}_{\mathrm{i}} \mathrm{y}_{\mathrm{i}}$. In Careaga and Weingast, there is no national public good to consider (or its level is exogenous), and $\beta$ is determined exogenously to subnational preferences. In that case, utility simply becomes $U\left(g_{n}, g_{-n}\right.$, $G, \theta)+f\left(m_{n}, g_{n}\right)-c_{n} g_{n} /(1-\beta)$, and the effect of the revenue sharing is to increase the effective marginal cost of the subnational public good. If the fact that the revenue sharing leads to an increased level of the public
} 
However, the appropriate comparison may not be with the Pareto optimal solution, but rather the centralized outcome achieved through political institutions. In that case, the preferences of the median jurisdiction are operative, and the externality effect is still present. Thus, this form of centralization is not superior to decentralization in this more realistic comparison. An alternative view of centralization would be that it aggregates the interests of different subnational jurisdictions through logrolling. This would be one conception, therefore, of cooperative federalism. ${ }^{11}$ In that case, one might argue that the logrolling process could lead to maximizing the sum of all utilities, as expressed in (8). An alternative would be to consider cooperative game solution concepts such as the Nash bargaining solution (NBS). In this case, the maximand would be the Nash product of individual jurisdictions' utility gains from cooperation, say $\Pi\left(U_{n}-U_{n}{ }^{0}\right)$. In this expression, $U_{n}$ is abbreviated notation for the utility expression in (7), and $U_{n}{ }^{0}$ is this expression evaluated at the noncooperative, decentralized outcome. ${ }^{12}$

In the latter formulation, the decentralized (or competitive) outcome acts as the threat point for cooperative bargaining. How cooperation is achieved is not fully specified, but it is not legally imposed in a federal system, since noncooperation remains feasible for individual jurisdictions. Note that, in the formulation used here, competition among jurisdictions is attenuated, since there is no mobility of factors of production. This seems reasonably realistic for countries such as India and China, where constraints or restrictions on internal mobility do exist, especially for labor. On the other hand, the implications of mobility have been worked out in an extensive literature, which justifies downplaying this aspect of competition here. ${ }^{13}$

One key aspect of decentralization that is preserved here is the ability of subnational jurisdictions to set taxes to finance local public goods. The Indian case is quite far from this situation, even after decentralization. States, and especially local

good is recognized, the reduced from utility, after eliminating $\beta$ has the form $U\left(g_{n}, g_{-n}, G, \theta\right)+f\left(m_{n}, g_{n}\right)$ $c_{n} g_{n}-c G c_{n} g_{n} / \Sigma c_{i} g_{i}$. This expression is very similar to (7), differing only in the last term. The difference there is that the tax-base-enhancing effect of increasing $g_{n}$ is not recognized, because of the way taxes are shared. However, the qualitative impact of this term on the choice of $g_{n}$ remains similar to the case of (7). Treisman (2006) analyzes a somewhat different model in which subnational retention can conflict with beneficial national level spending, so that the welfare effects are ambiguous.

${ }^{11}$ As Breton (1996) points out, cooperation ought not to be confused with hierarchical imposition of cooperative outcomes, which naturally occurs in a centralized system. Breton also uses the analogy of cartel instability to argue that horizontal cooperation cannot overcome certain kinds of inefficiencies presumably because binding agreements cannot be signed. However, a Coasian perspective would support the idea of efficient bargaining under some circumstances.

${ }^{12}$ Besley and Coate (2003) provide a complete analysis of the comparison between centralized and decentralized provision of subnational public goods in a particular case, with two subnational jurisdictions. They allow for preference heterogeneity within jurisdictions, spillovers, and also strategic manipulation of national representatives' preferences by subnational voters. However, there is no national public good in their model.

${ }^{13}$ A different approach to the benefits of subnational competition stresses the ability to benchmark more effectively at that level (Salmon, 1987). Thus, benchmarking promotes accountability. Of course, benchmarking can be used at the country level as well: comparisons of India and China are made by voters as well as academic analysts. Qian and Roland (1998) explicitly model competition for mobile capital, but do not have a national level public good in their framework. 
governments, rely substantially on transfers from higher level governments to finance subnational public goods. Consider the implications of making the extreme assumption of complete tax centralization, in the form of a uniform tax. In that case, (5) is replaced by

$$
\mathrm{x}_{\mathrm{n}}=(1-\mathrm{T}) \mathrm{y}_{\mathrm{n}} \text {. }
$$

Now there is a single national tax, which finances public goods at all levels. There is an aggregate budget constraint, which is

$(4)^{\prime} \quad \Sigma \mathrm{c}_{\mathrm{i}} \mathrm{g}_{\mathrm{i}}+\mathrm{cG}=\mathrm{T} \Sigma \mathrm{y}_{\mathrm{i}}$.

If only this aggregate constraint is recognized, then utility reduces to

(7) $\quad U\left(g_{n}, g_{-n}, G, \theta\right)+f\left(m_{n}, g_{n}\right)-\left(\Sigma c_{i} g_{i}+c G\right) f\left(m_{n}, g_{n}\right) / \Sigma f\left(m_{i}, g_{i}\right)$.

Clearly, this formulation indicates the standard common pool problem with respect to financing the local public good: each jurisdiction will prefer a higher level of $g_{n}$ than in (7), because the marginal cost is shared across all jurisdictions.

There is some ambiguity here as to how centralized decision-making would occur. If all public good levels, and hence also the tax rate, are voted on by each jurisdiction, then there is no ordering that allows application of median voter logic: each jurisdiction will seek to expand funding of its own local public good at the expense of others. ${ }^{14}$ Essentially, one is missing a rule for allocating the common pool. If there are lump sum transfers, say $R_{n}$, then the budget constraints become

$$
\mathrm{C}_{\mathrm{n}} \mathrm{g}_{\mathrm{n}}=\mathrm{R}_{\mathrm{n}} \text {. }
$$

However, the reduced form utility expression remains as in (7)', once the two budget constraints are aggregated. The difference in this case is that each preferred $g_{n}$ is determined by (3)'. Of course, all this does is shift the problem to that of determining the transfers. A rule such as 'equal transfers' may be used, or some other rule-based determination made, or there could be bargaining over these transfers. Both India and China's federal institutions exhibit some elements of such processes, combining both rules and bargaining. Note that if the transfers are somehow fixed exogenously, the first order condition for $\mathrm{G}$ has the same form in (7)' as in (7).

Bargaining or lobbying with respect to transfers potentially leads to soft budget constraints. An increase in $\mathrm{R}_{\mathrm{n}}$ directly benefits jurisdiction $\mathrm{n}$ by increasing the level of its subnational public good (equation (3)'), but the negative impact on the level of the national public good is mitigated by the common pool element. In this static framework, therefore, the problem of soft budget constraints is essentially the common pool problem. The concept of market-preserving federalism emphasizes the need to have hard budget constraints. In this case, that prescription is therefore equivalent to avoiding the common pool problem associated with centralized taxes and transfers downward. ${ }^{15}$

\footnotetext{
${ }^{14}$ The problem that voters at the national level have a multi-dimensional set of expenditure levels to vote on is an example of a larger problem, namely that accountability for a broader set of policies is difficult to enforce. Seabright (1996) offers one approach to formalizing this difference in accountability at different levels of government.

${ }^{15}$ Note that one can have separate subnational and national taxes, as well as transfers. In that case, transfers that are lump sum do not directly affect the marginal incentives of the subnational jurisdiction for determining its tax rate. However, there is an indirect impact, through the change in the financing of the national public good. The reduced form utility function is now $U\left(g_{n}, g_{-n}, G, \theta\right)+f\left(m_{n}, g_{n}\right)-c_{n} g_{n}-R_{n}-$
} 
A key element that is not captured in the above formulation is the low level of subnational public good provision in India, which has tended to have greater fiscal centralization than China. In fact, the common pool element in the last specification implies overspending on local public goods, the opposite of what is observed in India. Clearly, an important factor in determining patterns of public allocation is the preferences of decision-makers, which do not necessarily reflect those of constituents. Hence, we next consider an expanded model of government decision-making. ${ }^{16}$

Suppose, therefore, that some fraction of tax revenues is diverted at the local level, and consumed directly by government officials. Initially, suppose that there is no diversion at the national level. We will begin with the original formulation, with public goods at different levels financed by separate subnational and national taxes on output. Suppose that a fraction, $\mathrm{k}_{\mathrm{n}}$, of subnational tax revenues is diverted. This fraction is chosen by the government decision maker. Then the budget constraint for the subnational public good becomes

(3)" $\quad c_{n} g_{n}=\left(1-k_{n}\right) t_{n} y_{n}$.

The objective function of the government decision-maker is a weighted sum of constituent utility and private gain:

$$
\mathrm{U}\left(\mathrm{g}_{\mathrm{n}}, \mathbf{g}_{-\mathrm{n}}, \mathrm{G}, \theta\right)+\left(1-\mathrm{t}_{\mathrm{n}}-\mathrm{T}\right) \mathrm{y}_{\mathrm{n}}+\alpha \mathrm{W}\left(\mathrm{k}_{\mathrm{n}} \mathrm{t}_{\mathrm{n}} \mathrm{y}_{\mathrm{n}}\right) .
$$

Here, $\alpha$ is the relative weight given to private gain, and is exogenously determined, and $\mathrm{W}($.) is a strictly concave function.

Now the reduced form utility function becomes

$$
\begin{aligned}
& U\left(g_{n}, g_{-n}, G, \theta\right)+f\left(m_{n}, g_{n}\right)-c_{n} g_{n} /\left(1-k_{n}\right)-c G f\left(m_{n}, g_{n}\right) / \Sigma f\left(m_{i}, g_{i}\right) \\
& +\alpha W\left(k_{n} c_{n} g_{n} /\left(1-k_{n}\right)\right) .
\end{aligned}
$$

To investigate the choice of $k_{n}$, let $k_{n} c_{n} g_{n} /\left(1-k_{n}\right)=h_{n}$. Then the utility function becomes $(7)^{\prime \prime \prime} \quad U\left(g_{n}, g_{-n}, G, \theta\right)+f\left(m_{n}, g_{n}\right)-c_{n} g_{n}-h_{n}-c G f\left(m_{n}, g_{n}\right) / \Sigma f\left(m_{i}, g_{i}\right)+\alpha W\left(h_{n}\right)$. Hence the first-order condition that determines $\mathrm{k}_{\mathrm{n}}$ can be written simply as

$$
\alpha \mathrm{W}^{\prime}\left(\mathrm{h}_{\mathrm{n}}\right)=1 \text {. }
$$

As shown in the appendix, when (9) holds, the first order condition for $g_{n}$ is unaffected by the presence in the objective function of the extra term $\alpha \mathrm{W}\left(\mathrm{k}_{\mathrm{n}} \mathrm{t}_{\mathrm{n}} \mathrm{y}_{\mathrm{n}}\right)$. Thus, constituents pay more in taxes, but the level of the subnational public good is unaffected by the partially self-interested government decision-maker.

The intuition for this result is as follows. The government official's take depends on the size of the subnational tax base. Hence, it is not in his or her interest to distort the

$\left(c G+\Sigma R_{i}\right) f\left(m_{n}, g_{n}\right) / \Sigma f\left(m_{i}, g_{i}\right)$. The lump-sum transfers do have an impact on the incentive to set $g_{n}$, since increasing $g_{n}$ increases national taxes which partly go for transfers. Indeed, we see from this expression that an individual jurisdiction would prefer to set $\mathrm{R}_{\mathrm{n}}$ equal to zero, ceteris paribus, since it has only a negative impact on subnational welfare. This relates to the general problem of transfer dependence (e.g., Rodden, 2006), which exists independently of issues with respect to the marginal incentives embodied in the transfer rules.

${ }^{16}$ Such modeling has numerous antecedents. A recent important set of articles by Bardhan and Mookherjee (2005, 2006) provide references, literature overviews and specific models. 
level of the subnational public good, which is therefore set as if there were no diversion and no weighting of private gain. This result may be seen as broadly consistent with the Chinese case, where subnational government decision-makers act according to their own interests, as well as those of their constituents, but the outcome is still to optimize the size of the local tax base.

Now consider the polar case of a central decision-maker who captures a fraction, say, $\mathrm{k}$, of central taxes. Local decision makers simply carry out constituent preferences. Let $\mathrm{V}($.$) be the utility from this diversion, and \gamma$ the relative weight assigned to it. The utility function now becomes

$$
\mathrm{U}\left(\mathrm{g}_{\mathrm{n}}, \mathbf{g}_{-\mathrm{n}}, \mathrm{G}, \theta\right)+\left(1-\mathrm{t}_{\mathrm{n}}-\mathrm{T}\right) \mathrm{y}_{\mathrm{n}}+\gamma \mathrm{V}\left(\mathrm{kT} \Sigma \mathrm{y}_{\mathrm{n}}\right) .
$$

The reduced form for this is

$$
\begin{aligned}
& \mathrm{U}\left(\mathrm{g}_{\mathrm{n}}, \mathbf{g}_{-\mathrm{n}}, \mathrm{G}, \theta\right)+\mathrm{f}\left(\mathrm{m}_{\mathrm{n}}, \mathrm{g}_{\mathrm{n}}\right)-\mathrm{c}_{\mathrm{n}} \mathrm{g}_{\mathrm{n}}-\operatorname{cGf}\left(\mathrm{m}_{\mathrm{n}}, \mathrm{g}_{\mathrm{n}}\right) /\left((1-\mathrm{k}) \Sigma \mathrm{f}\left(\mathrm{m}_{\mathrm{i}}, \mathrm{g}_{\mathrm{i}}\right)\right) \\
& +\gamma \mathrm{V}(\mathrm{kcG} /(1-\mathrm{k})) .
\end{aligned}
$$

Using an argument similar to before, one can show that the optimal choice of $\mathrm{k}$ leads to no distortion in the central decision-maker's preferred choice of G. ${ }^{17}$ The choice of $\mathrm{g}_{\mathrm{n}}$, however, should be made at the subnational level, in which case the last term in (11) drops out. Nevertheless, the diversion by the central decision-maker enters the second-last term in (11) and has the effect of increasing the effective cost of the subnational public good, leading to underprovision on that score. This same effect would still be operative if there are also transfers from the national level to subnational governments, or if subnational public goods are funded through national taxes and intergovernmental transfers.

Therefore, the last formulation gets at some of the features of the Indian case, where the objectives of higher-level government decision-makers may lead to underprovision of subnational public goods. However, the magnitude of the underprovision in the Indian case, which will be brought out empirically in the next section, may be greater than can be explained by the kind of effect modeled here. Rao and Singh (2003) provide an alternative modeling approach, where there are multiple equilibria due to discontinuities, and low efficiency of local government expenditure leads to a low expenditure outcome.

\section{Comparing the Decentralization Cases}

A salient feature of the Chinese case is the success of town and village enterprises (TVEs) in contributing to economic development. In 1993, TVEs and other small rural enterprises contributed an estimated 36 percent of China's industrial output, far more than the share of large firms (Bouckaert, 2006, Figure 2). The organizational nature of, and incentive structures implemented in TVEs have been well-studied (e.g., Fu and Balasubramanyam, 2003; Li and Fang, 1997; Bouckaert, 2006), and the impact on growth has been empirically documented (DaCosta and Carroll, 2000; Jin, Qian and Weingast,

\footnotetext{
${ }^{17}$ Here one can assume that the subnational jurisdiction which enters the decision-maker's utility function is the median one, when ordered by preferences over G, though this assumes the ordering is independent of the subnational good levels.
} 
2005). A case has been made, theoretically (Qian and Roland, 1998) and empirically (Qian and Weingast, 1996), that decentralization with hard budget constraints has characterized this process, so that the Chinese case is an illustration of de facto MPF.

India, on the other hand, has lacked any effective decentralization until the 1990s, when state governments began to have some control over economic policies affecting private investment (Singh and Srinivasan, 2005). At about the same time, political decentralization to the local level began with constitutional amendments to create stronger elected local governments. This political decentralization has not been accompanied by any significant devolution of funds or authority over local-level economic decision-making (e.g., Rao and Singh, 2003; World Bank, 2004). This contrast with the Chinese case is important, and deserves to be highlighted. However, we argue here that the Chinese experience has additional features that often parallel the issues facing subnational governments in India.

We will develop three points with respect to fiscal and policy decentralization in China and India. First, China has benefited from greater policy decentralization to the provinces, the highest subnational level, as well as some decentralization to local governments. Second, problems of soft budget constraints, unclear expenditure assignments, insufficient revenue authority, poor fiscal management and, finally, inadequate provision of local public goods affect both countries in very similar ways. Third, the nature of federalism in both countries is more complex than can be encompassed with any of the three well-known conceptual schemes discussed in the previous section.

Understanding the Chinese experience is complicated by the fact that theoretical discussions applied to China (e.g., Qian and Roland, 1998) often refer to all subnational governments as local. Empirical analyses that emphasize hard budget constraints and high retention rates work with provincial data (Jin, Qian and Weingast, 2005). In fact, the difference between fiscal situations at the provincial and truly local levels is quite significant. In particular, local governments in China have been given unfunded expenditure responsibilities by provinces, and they have found it difficult to meet obligations for providing local public goods (e.g., Bahl and Martinez-Vazquez, 2005; Lin, Tao and Liu, 2006). While it has been argued that hard budget constraints at the local level have spurred privatization (Cao, Qian and Weingast, 1999), other studies suggest that local governments have used extra-budgetary operations, including political linkages with local banks, to soften budget constraints and amass significant liabilities (e.g., Jin and Zou, 2003; Lin, Tao and Liu, 2006). Shah and Shen (2006) document the nature and extent of transfers at the subprovincial level, and their calculations, based on unpublished data from the Ministry of Finance, indicate that local governments are very significant in carrying out expenditure responsibilities (Table 2), though the degree of autonomy is probably severely constrained.

In fact, much of the success of China's TVEs was initiated under the early reform regime, where tax authority was significantly decentralized. In the 1980s, central tax revenues fell, and prompted the recentralization of fiscal authority in 1994. Thus, China 
is not a clear cut case of fiscal decentralization. Certainly, economically powerful provinces were able to bargain for provisions in the new system that protected their shares of overall government revenues (e.g., Bahl and Martinez-Vazquez, 2005). However, they were relatively squeezed, compared to the early reform period, and local governments bore the brunt of this squeeze. It remains the case, however, that local governments have retained economic authority, and de facto fiscal authority (significantly through off-budget activities) than has ever been the case in India.

India's constitutional and other legal and administrative structures with respect to center-state fiscal relations and general power-sharing have not changed significantly in the decades since the constitution was ratified, in 1950. The conduct of electoral politics did lead to ebbs and flows in the effective degree of political centralization in the 1960s and 1970s. However, economic centralization did increase throughout the period, until the 1980s, including nationalization of banks and other financial sector institutions, as well as more extensive controls of private sector economic activity. Major changes occurred after 1991, when the removal of most national-level industrial licensing controls allowed states to more freely pursue independent economic policies (Singh and Srinivasan, 2005).

The states, starting also from quite different initial conditions, have had varying responses to the 1990s policy decentralization, and the result has been greater regional inequality (e.g., Rao and Singh, 2005), though perhaps not as extreme as in China. These developments were accompanied by a broadening of the scope given by the national government to the Finance Commission, allowing it to make recommendations on a complete range of issues pertaining to the public finances (Rao and Singh, 2007). However, the essentials of the intergovernmental transfer system (including Planning Commission and central-ministry-mediated transfers) have remained relatively unchanged, reflecting both respect for precedent and bureaucratic inertia. In particular, the transfer system is still a contributory factor to soft budget constraints at the state level, because of the use of "gap-filling" grants based partly on ex post needs. ${ }^{18}$ To the extent that horizontal equalization considerations are built into the transfer formulas, centerstate transfers in India involve lower effective "retention"19 of revenues generated by state tax bases (Singh and Srinivasan, 2006), which may reduce incentives for subnational stimulation of private economic activity (Careaga and Weingast, 2001).

The significant legal change that occurred in 1993 was the passage of two constitutional amendments creating local governments with mandated electoral accountability and provisions for an explicit system of state-local transfers Rao and Singh, 2003; Chaudhuri, 2006). Earlier the composition, financing and even existence of local governments were completely at the discretion of state governments. While the new

\footnotetext{
${ }^{18}$ This characterizes aspects of both Finance Commission and Planning Commission transfers. The states' budget constraints are also softened by access to captive finance in the form of shares of National Small Savings, a rural postal saving scheme (Rao and Singh, 2007).

${ }^{19}$ The inverted commas indicate that this is not retention in the sense of the center appropriating a fraction of revenues raised by the states. The formulas apply to revenues from taxes that are constitutionally assigned to, and collected by, the central government, but required, also by the constitution, to be shared.
} 
legislation gave greater apparent expenditure authority to local governments, in practice, with one or two exceptions, state governments continue to exercise effective authority over local expenditures, since local government budgets rely almost exclusively on transfers from above. With the exception of a few major cities, virtually all decisions of economic consequence for local governments are effectively taken at the state or national level. In 2002-03, rural local governments' own source revenues were less than 7 percent of their total revenue and less than 10 percent of their current expenditures. Urban local bodies did somewhat better, raising about 58 percent of their revenue and covering almost 53 percent of their expenditure from own revenue sources. However, aggregate local government expenditure constituted only about 5 percent of total government spending at all levels.

Despite the strong contrast between China and India in the policy discretion afforded to local governments, there have been several similarities. While rural local governments in India were mostly nonentities until the 1990s reforms, its towns and cities were governed by local councils, typically appointed, and overseen by bureaucrats from the elite Indian Administrative Service (IAS), who also served as chief administrators for rural districts. ${ }^{20}$ Despite this nominally strong hierarchical oversight, India's city governments had a poor track record in terms of providing local public goods and in maintaining financial health (Rao and Singh, 2003). This situation has not changed appreciably in most of India's towns and cities even after local government reform, and parallels the problems of China's local governments (Martinez-Vazquez and Rider, 2005). ${ }^{21}$ In both cases, poor fiscal management practices continue, and their continuation is permitted by lack of transparency, including soft, as well as uncertain, budget constraints. In both countries, local governments lack adequate tax instruments, and the incentive to implement them effectively. In both, they still rely on transfers from the state government, and in China, as noted earlier, extra-budgetary operations and politicized bank lending are additional alternatives to local taxation.

At the local level, therefore, there is evidence that all the elements of the MPF framework are not operative in the Chinese case. In fact, what marks the Chinese situation at the local level, and distinguishes from India, is the second MPF condition, namely, primary authority over local economies for subnational governments. In both countries, there is a well-defined hierarchy of governments. Both lack full internal common markets, and both seem to exhibit soft budget constraints at the local government level. ${ }^{22}$ In fact, after its 1993 local government reforms, India seems to satisfy the last condition for MPF, namely, institutionalized allocation of political authority, more closely than China at this level.

\footnotetext{
${ }^{20}$ The district is the major sub-state administrative unit in India - there are two smaller units below it in rural areas, the block and the village-group. Thus, the number of levels and spans of control in India and China are quite similar, albeit with very different political and administrative practices.

${ }^{21}$ In this respect, the model of Qian and Roland (1998) is useful in distinguishing two dimensions of public expenditure, local public goods and infrastructure for private economic activity. Of course, in reality, the two are not independent, but overlap. The model of the previous section recognizes this, but goes to the other extreme of combining the two dimensions.

${ }^{22}$ On the lack of common markets, for China, see Bahl and Martinez-Vazquez (2005), and for India see Rao and Singh (2005).
} 
Interestingly, the decentralization of economic authority in China down to the local government level appeared to take place through the operation of a centralized political hierarchy (e.g., Qian, Roland and Xu, 1999; Bahl and Martinez-Vazquez, 2005). Provincial and local officials of the ruling Communist party were given signals that they should focus on economic success, and rewarded directly and accordingly for achievements in this dimension. This created a form of benchmark competition very different from what would operate through electoral accountability. ${ }^{23}$

One is led toward two preliminary conclusions. First, at least in the short run, the nature of competition and incentives that operate at the subnational level may be what is important, rather than the other elements of MPF. There is, of course, an extensive literature that examines the impacts of subnational competition: efficiency does not always emerge as the equilibrium outcome. In China, local governments just happened to be the vehicle for fostering private sector competition, and did not engage in standard fiscal competition. Second, China's example, of political centralization and economic decentralization, may not be one that is generally applicable, since it relies on structures that may not be transferable to other contexts. This issue is aside from any intrinsic value one would likely assign directly to political freedom. Certainly, this latter point is critical for thinking about any lessons for India from China's experience.

One might view the discussion so far as supporting a view of the role of government competition in federal systems that is broader (e.g., Breton, 1996) than the pure MPF definition. On the other hand, there appears to be a stronger case for applying the MPF idea at the province/state level in the two countries. Certainly, it is the case that China does not have any explicit equalizing system of intergovernmental transfers (ADB, 200x; Qian and Weingast, 1999), and this implies greater subnational tax retention at the margin, and harder budget constraints than in the Indian case. One can also argue that the success of TVEs can ultimately be traced to decentralization at the provincial level. In that case, more of the MPF conditions are validated at the provincial as opposed to the local level. However, it is still true that the implementation of economic decentralization in China required the existence of a party hierarchy that stretched down effectively to the local level. This condition is not satisfied in India, except perhaps in the state of West Bengal, with its own ruling Communist party. Bureaucratic hierarchies in India did not serve this role, though perhaps they could have if central authorities had made local economic success a benchmark for bureaucratic career advancement, similarly to what happened in China. ${ }^{24}$

\footnotetext{
${ }^{23}$ Qian, Roland and Xu (1999) model this formally as an M-form, or multidivisional organization.

${ }^{24}$ It is also true that social fragmentation and vertical divisions are more salient in India. These factors have been shown empirically to affect the provision of local public goods in that country (Banerjee et al, 2005; Banerjee and Iyer, 2005; Banerjee and Somanathan, 2007; Kochar et al, 2006), and may reduce the ability or collective desire for such provision, as well as distort the pattern of provision, whatever are the incentive structures of local bureaucrats or political decision-makers. Also, Chhibber, Shastri and Sisson (2003) used surveys of citizens across India, and found that certain kinds of public goods that might be more reflective of social homogeneity, such as neighborhood cleanliness, pollution and crime were perceived as unimportant. Bardhan and Mookherjee $(2005,2006)$ also explore the implications of inequality for decentralization outcomes.
} 
While decentralization obviously may spur competition among subnational governments in a federal system, it also increases the potential role of cooperation, enforced through legally binding rules or agreements (perhaps mediated by hierarchical monitoring and facilitation), or through self-enforcing mechanisms such as repeated interaction and reputation. The Chinese case does not seem to illustrate cooperative federalism in this sense. The central government and the more economically powerful provinces compete for shares of the fiscal pie, but the poorer provinces appear to be left out of this bargaining. However, internal Communist Party workings may provide an arena for some kind of cooperative bargaining.

India in the 1950s and early 1960s also had a system where bargaining took place within the ruling party's organization. However, several more formal bargaining forums have emerged. Both the Inter-State Council (since 1990) and the earlier (but narrower in scope) National Development Council provide mechanisms for the center and state governments to reach agreement on issues such as tax harmonization and intergovernmental transfers (e.g., Rao and Singh, 2005; Singh and Srinivasan, 2005). In addition, the emergence of multi-party coalitions in the central government has made bargaining more explicit in the national legislature. In many respects, therefore, the recent working of India's federal system corresponds to cooperative federalism. However, in neither country do there appear to be mechanisms for cooperation among local governments. India and China's local governments share the characteristic of being “overawed” (to use Riker's term for characterizing the central government's strength in a federation) by state and provincial governments, respectively.

To summarize the possible lessons of the two decentralization cases, China does appear to satisfy some aspects of MPF, especially at the provincial level, but hard budget constraints are not clearly present for local governments. The main distinguishing feature of the Chinese case is the greater authority of subnational governments with respect to economic activity. However, the incentive and control mechanisms for this assignment appear to be a form of political-cum-bureaucratic centralization that may not be a transferable model. In India, on the other hand, while economic decentralization has progressed down to the state level, local governments still have negligible fiscal or policy clout. Nevertheless, with some progress in its formal institutional structures, India may provide a more promising case for testing the MPF concept. In particular, attempts to provide market borrowing mechanisms for state and local governments may be a more durable route to hard budget constraints than Chinese bureaucratic authoritarianism.

\section{Conclusions}

The contribution of this paper is to compare the fiscal decentralization experience of India and China in the context of commonly used conceptual frameworks of federalism, namely, competitive, cooperative and market-preserving federalism. The goal of this comparison is to understand better the impact of federal institutions on economic development. While some authors have described China as fitting well into the MPF framework, and the country's experience indeed appears to reflect hard budget 
constraints at the provincial level and decentralization of control over economic activity, the special features of the Chinese case make it an awkward exemplar of MPF. In particular, the special role of China's political and bureaucratic structures, including the use of strong intra-party incentives - even stronger than one would find in a multidivisional firm ${ }^{25}$ - makes it unique. Competition among local governments has worked significantly through these incentive structures, rather than the standard economic model of subnational jurisdictions competing to satisfy constituents.

The Indian case is one where economic decentralization has lagged behind China considerably. After economic reform, states have been able to pursue economic policies with greater freedom, and this, together with the emergence of coalition governments at the national level, has laid the groundwork for some elements of cooperative federalism. However, formal political decentralization to the local level without adequate devolution of economic powers to local governments has not achieved any significant change in the division of responsibility between state and local governments. This contrasts strongly with China, where subprovincial governments have much greater responsibility. The theoretical modeling exercise in this paper suggests that this greater local autonomy may contribute to economic development. In both countries, the greatest problems arise at the local level, with lack of adequate tax bases for the expenditure responsibilities that have been assigned, either by law (India) or through politico-bureaucratic decisions (China). This situation is combined with, and contributes to, soft budget constraints, especially at the local level for China, and somewhat at the state level for India. Hence, both countries may benefit from similar reforms to achieve more efficient decentralization to the local level, with greater sources of own revenue, transfers that do not distort incentives, and budget constraints that are firmer and subject to market discipline.

\section{Appendix}

\section{Proof of Claim in Section 3}

Using the formulation in section 3, the budget constraint for the subnational public good is

$$
\mathrm{c}_{\mathrm{n}} g_{\mathrm{n}}=\left(1-\mathrm{k}_{\mathrm{n}}\right) \mathrm{t}_{\mathrm{n}} \mathrm{y}_{\mathrm{n}}
$$

The objective function of the government decision-maker is a weighted sum of constituent utility and private gain:

$$
\mathrm{U}\left(\mathrm{g}_{\mathrm{n}}, \mathbf{g}-\mathrm{n}, \mathrm{G}, \theta\right)+\left(1-\mathrm{t}_{\mathrm{n}}-\mathrm{T}\right) \mathrm{y}_{\mathrm{n}}+\alpha \mathrm{W}\left(\mathrm{k}_{\mathrm{n}} \mathrm{t}_{\mathrm{n}} \mathrm{y}_{\mathrm{n}}\right),
$$

where $\alpha$ is the relative weight given to private gain, and is exogenously determined, and $\mathrm{W}($.$) is a strictly concave function.$

The reduced form utility function is

$$
\begin{aligned}
& U\left(g_{n}, g_{-n}, G, \theta\right)+f\left(m_{n}, g_{n}\right)-c_{n} g_{n} /\left(1-k_{n}\right)-\operatorname{cGf}\left(m_{n}, g_{n}\right) / \Sigma f\left(m_{i}, g_{i}\right) \\
& +\alpha W\left(k_{n} C_{n} g_{n} /\left(1-k_{n}\right)\right) .
\end{aligned}
$$

\footnotetext{
${ }^{25}$ In particular, punishments in China can be more severe than simply firing the individual concerned.
} 
Let $k_{n} c_{n} g_{n} /\left(1-k_{n}\right)=h_{n}$. Then the utility function is

(7)"' $\quad \mathrm{U}\left(\mathrm{g}_{\mathrm{n}}, \mathrm{g}_{-\mathrm{n}}, \mathrm{G}, \theta\right)+\mathrm{f}\left(\mathrm{m}_{\mathrm{n}}, \mathrm{g}_{\mathrm{n}}\right)-\mathrm{c}_{\mathrm{n}} \mathrm{g}_{\mathrm{n}}-\mathrm{h}_{\mathrm{n}}-\mathrm{cGf}\left(\mathrm{m}_{\mathrm{n}}, \mathrm{g}_{\mathrm{n}}\right) / \Sigma \mathrm{f}\left(\mathrm{m}_{\mathrm{i}}, \mathrm{g}_{\mathrm{i}}\right)+\alpha \mathrm{W}\left(\mathrm{h}_{\mathrm{n}}\right)$.

Hence the first-order condition that determines $\mathrm{k}_{\mathrm{n}}$ is

$$
\alpha \mathrm{W}^{\prime}\left(\mathrm{h}_{\mathrm{n}}\right)=1 \text {. }
$$

Differentiating (7)" with respect to $g_{n}$, we have

$$
\frac{\partial \mathrm{U}}{\partial \mathrm{g}_{\mathrm{n}}}+\frac{\partial \mathrm{f}}{\partial \mathrm{g}_{\mathrm{n}}}-\frac{\mathrm{c}_{\mathrm{n}}}{\left(1-\mathrm{k}_{\mathrm{n}}\right)}-\mathrm{cG} \frac{\partial}{\partial \mathrm{g}_{\mathrm{n}}}\left(\frac{\mathrm{f}}{\sum \mathrm{f}}\right)+\alpha \mathrm{W}^{\prime}\left(\frac{\mathrm{k}_{\mathrm{n}} \mathrm{c}_{\mathrm{n}} \mathrm{g}_{\mathrm{n}}}{\left(1-\mathrm{k}_{\mathrm{n}}\right)}\right) \frac{\mathrm{k}_{\mathrm{n}} \mathrm{c}_{\mathrm{n}}}{\left(1-\mathrm{k}_{\mathrm{n}}\right)}=0 .
$$

Using (9), this reduces to

$$
\frac{\partial \mathrm{U}}{\partial \mathrm{g}_{\mathrm{n}}}+\frac{\partial \mathrm{f}}{\partial \mathrm{g}_{\mathrm{n}}}-\frac{\mathrm{c}_{\mathrm{n}}}{\left(1-\mathrm{k}_{\mathrm{n}}\right)}-\mathrm{cG} \frac{\partial}{\partial \mathrm{g}_{\mathrm{n}}}\left(\frac{\mathrm{f}}{\sum \mathrm{f}}\right)+\frac{\mathrm{k}_{\mathrm{n}} \mathrm{c}_{\mathrm{n}}}{\left(1-\mathrm{k}_{\mathrm{n}}\right)}=0 .
$$

Combining the third and last terms, we get

$$
\frac{\partial \mathrm{U}}{\partial \mathrm{g}_{\mathrm{n}}}+\frac{\partial \mathrm{f}}{\partial \mathrm{g}_{\mathrm{n}}}-\mathrm{c}_{\mathrm{n}}-\mathrm{cG} \frac{\partial}{\partial \mathrm{g}_{\mathrm{n}}}\left(\frac{\mathrm{f}}{\sum \mathrm{f}}\right)=0,
$$

which is the equivalent to the first order condition without any diversion of funds or weighting of the decision-maker's interests.

\section{References}

Asian Development Bank (2005), Strengthening Macroeconomic and Fiscal Coordination in the People's Republic of China, Technical Assistance Consultant's Report, Number:

36150 January

Bahl, Roy and Jorge Martinez-Vazquez (2005), Fiscal Federalism and Economic Reform in China, in T.N. Srinivasan and Jessica Wallack, eds., Federalism and Economic Reform: International Perspectives, Cambridge, UK: Cambridge University Press.

Banerjee, Abhijit V., and Lakshmi Iyer, (2004), History, Institutions and Economic Performance: The Legacy of Colonial Land Tenure Systems in India, American Economic Review, 95 (4): 1190-1213.

Banerjee, Abhijit V., Lakshmi Iyer, and Rohini Somanathan (2005), History, Social Divisions and Public Goods in Rural India, Journal of the European Economic Association, 3 (2-3): 639-647.

Banerjee, Abhijit V., and Rohini Somanathan (2007), The Political Economy of Public Goods: Some Evidence from India, Journal of Development Economics, 82 (2): 287-314.

Bardhan Pranab and Dilip Mookherjee (2005), Decentralizing antipoverty program delivery in developing countries, Journal of Public Economics, 89 , pp. 675- 704. 
Bardhan Pranab and Dilip Mookherjee (2006), Pro-poor targeting and accountability of local governments in West Bengal, Journal of Development Economics, 79, 303- 327.

Besley, Timothy , and Stephen Coate (2005), Centralized versus decentralized provision of local public goods: a political economy approach, Journal of Public Economics, 87, pp. 2611- 2637.

Bouckaert, Boudewijn R.A. (2006), Bureaupreneurs in China: We Did it Our Way - A Comparative Study of the Explanation of the Economic Successes of Town-VillageEnterprises In China, working paper 13, International Centre for Economic Research, University of Ghent.

Breton, Albert (1987), Towards a Theory of Competitive Federalism, European Journal of Political Economy, vol. 3, nos. 1-2, 263-329.

Breton, Albert (1996), Competitive Governments: An Economic Theory of Politics and Public Finance, Cambridge University Press, New York.

Cao, Yuanzheng, Yingyi Qian, and Barry R. Weingast (1999), From Federalism, Chinese Style, to Privatization, Chinese Style, Economics of Transition. vol 7 no. 1: 103-31.

Careaga, Maite, and Barry Weingast, 2001, Fiscal Federalism, Good Governance, and Economic Growth in Mexico, working paper, Stanford University

Chaudhuri, Shubham (2006), What difference does a constitutional amendment make? The 1994 Panchayati Raj Act and the attempt to revitalize rural local government in India, in Decentralization and Local Governance in Developing Countries, (ed.) Pranab Bardhan and Dilip Mookherjee, Cambridge, MA: MIT Press, 153-201.

Chhibber, Pradeep, Sandeep Shastri, and Richard Sisson (2003), The State, Voluntary Associations, and the Provision of Public Goods in India, working paper, University of California, Berkeley.

DaCosta, Maria, Carroll Wayne (2001), Township and village enterprises, openness and regional economic growth in China, Post-Communist Economies 13 (2), 229-241.

Fedelino, Annalisa and Teresa Ter-Minassian, (2006), Intergovernmental Fiscal Relations in China, Paper presented at the Stanford Conference on Economic Challenges in Asia, June 1-3.

Finance Commission (2004), Report of the Twelfth Finance Commission (2005-10), November, http://fincomindia.nic.in/Report of 12th Finance Commission/index.html.

Fu, Xiaolan, and V.N. Balasubramanyam (2003), Township and Village Enterprises in China, Journal of Development Studies, Vol.39, No.4, April, pp.27-46.

Heady, Christopher (1998), Local Government Finance and Industrial Policy in China, Economics of Planning 31: 195-212. 
Jin, Hehui, Yingyi Qian, and Barry R. Weingast (2005), Regional decentralization and fiscal incentives: Federalism, Chinese style, Journal of Public Economics 89, 1719-1742.

Jin, Jing, and Heng-fu Zou (2003), Soft Budget Constraints and Local Government in China, in Fiscal Decentralization and the Challenge of Hard Budget Constraints, (ed.) Jonathan Rodden, Gunnar Eskeland, and Jennie Litvack, Cambridge, MA: MIT Press, 289-323.

Kochar, Anjini, Kesar Singh and Sukhwinder Singh (2006), Targeting Public Goods to the Poor in a Segregated Economy: An Empirical Analysis of Central Mandates in Rural India, working paper, Stanford University, October.

Li, Ji and Yongqing Fang (1997), the Inter-Organisational Learning Process of China's Township Enterprises, working paper, National University of Singapore.

Lin, Justin Yifu, Ran Tao and Mingxing Liu (2006), Decentralization and Local Gvoernance in China's Economic Transition, in Decentralization and Local Governance in Developing Countries, (ed.) Pranab Bardhan and Dilip Mookherjee, Cambridge, MA: MIT Press, 305-327.

Martinez-Vazquez, Jorge, and Mark Rider (2005), Fiscal Decentralization and Economic Growth: A Comparative Study of China and India, working paper 05-19, Andrew Young School of Policy Studies, Georgia State University, October.

Montinola, Gabriella, Yingyi Qian, and Barry R. Weingast (1995), “Federalism, Chinese Style.” World Politics. 48(1): 50-81.

Parikh, Sunita and Barry Weingast (1997), A Comparative Theory of Federalism: India, Virginia Law Review, 83(7), 1593-1615.

Qian, Yingyi, and Gerard Roland (1998), Federalism and the Soft Budget Constraint, American Economic Review, Vol. 88, No. 5, pp. 1143-1162.

Qian Yingyi, Gerard Roland, and Chenggang Xu (1999), Why is China different from Eastern Europe? Perspectives from organization theory, European Economic Review, 43, $085-1094$.

Qian, Yingyi, and Barry R. Weingast, (1996), China’s transition to markets: marketpreserving federalism, Chinese Style, Journal of Policy Reform 1, 149- 185.

Rao, M. Govinda (2003), Challenges of Fiscal Decentralization in Developing and Transitional Economies: An Asian Perspective, in James Alm and Jorge MartinezVazquez, Public Finance in Developing and Transitional Countries, Northampton, MA: Edward Elgar, pp. 35-62.

Rao, M. Govinda, and Nirvikar Singh (2003), How to Think About Local Government Reform in India, in Economic Reform and the Liberalisation of the Indian Economy: Essays in Honour of Richard T. Shand, ed., K.P. Kalirajan. Edward Elgar., pp. 335-390 
Rao, M. Govinda, and Nirvikar Singh (2005), Political Economy of Federalism in India, New Delhi, Oxford University Press.

Rao, M. Govinda, and Nirvikar Singh (2007), The Political Economy of India's Fiscal Federal System and its Reform, Publius: The Journal of Federalism, 37: 26-44.

Reserve Bank of India (2006), Annual Report, Reserve Bank of India: Mumbai.

Rodden, Jonathan and Susan Rose-Ackerman, (1997), Does Federalism Preserve Markets?, Virginia Law Review, 83, 1521.

Salmon, Pierre (1987), Decentralization as an Incentive Scheme, Oxford Review of Economic Policy, 3, 2, pp. 24-43.

Seabright, Paul (1996), “Accountability and Decentralization in Government: An Incomplete Contracts Model”, European Economic Review, 40, 61-89.

Shah Anwar and Chunli Shen (2006), The Reform of the Intergovernmental Transfer System to Achieve a Harmonious Society and a Level Playing Field for Regional Development in China, World Bank Policy Research Working Paper 4100, December.

Singh, Nirvikar, and T.N. Srinivasan (2005), "Indian Federalism, Globalization and Economic Reform,” in T.N. Srinivasan and Jessica Wallack, eds., Federalism and Economic Reform: International Perspectives, Cambridge, UK: Cambridge University Press.

Treisman, Daniel (2006), Fiscal decentralization, governance, and economic performance: a reconsideration, Economics and Politics, 18, 2, pp.219-35.

Weingast, Barry, (1993), Constitutions as Governance Structures: The Political Foundations of Secure Markets, Journal of Institutional and Theoretical Economics, 149, 233-61. 
Table 1: Subnational Government Tiers

\begin{tabular}{cccc}
\hline \multicolumn{1}{c}{ China } & \multicolumn{2}{c}{ India } \\
\hline $\begin{array}{c}\text { Type } \\
\begin{array}{c}\text { Province+municipality+ } \\
\text { autonomous region } \\
\text { Prefecture }\end{array}\end{array}$ & $\begin{array}{c}\text { Number } \\
22+4+5\end{array}$ & $\begin{array}{c}\text { Type } \\
\text { State+national capital } \\
\text { territory+union territory } \\
\text { District+municipal } \\
\text { corporation }\end{array}$ & $\begin{array}{c}\text { Number } \\
28+1+6\end{array}$ \\
$\begin{array}{c}\text { County/city } \\
\text { Township }\end{array}$ & 31 & $\begin{array}{c}\text { Block+municipality } \\
\text { Village+township }\end{array}$ & $540+109$ \\
& 2,109 & & $236,350+2,182$ \\
\hline
\end{tabular}

Sources: Fedelino and Ter-Minassian (2006), Finance Commission (2004)

Notes: 1. The four Chinese municipalities are Beijing, Shanghai, Tienjin, and Chongqing. These, and the autonomous regions, are essentially at the same level as provinces. 2 . The Indian figures denote three tiers of rural and urban governments respectively. Tiers of rural governments effectively form a hierarchy, whereas urban governments are categorized by size and, partly, sophistication of operations.

Table 2: Subnational Revenues and Expenditures in China, 2003

\begin{tabular}{lcc}
\hline Governmental level & Share of Revenues & Share of Expenditures \\
\hline Central & 71.0 & 30.1 \\
Provincial & 5.7 & 18.5 \\
Subprovincial & 23.3 & 51.4 \\
\hline
\end{tabular}

Source: Shah and Shen (2006), Table 6. 